\title{
The Greening and Wetting of the Sahel Have Leveled off since about 1999 in Relation to SST
}

\author{
Tiexi Chen ${ }^{1, *}$, Shengjie Zhou ${ }^{1}$, Chuanzhuang Liang ${ }^{1}$, Daniel Fiifi Tawia Hagan ${ }^{1}{ }^{(\mathbb{D}}$, \\ Ning Zeng ${ }^{2,3}$, Jun Wang ${ }^{4}\left(\mathbb{D}\right.$, Tingting Shi ${ }^{5}$, Xin Chen ${ }^{1}$ and A.J. Dolman ${ }^{1,6}$ \\ 1 Collaborative Innovation Center on Forecast and Evaluation of Meteorological Disaster, School of \\ Geographical Sciences, Nanjing University of Information Science \& Technology, Nanjing 210044, China; \\ 20181210015@nuist.edu.cn (S.Z.); 20181210009@nuist.edu.cn (C.L.); dans7messiah@nuist.edu.cn (D.F.T.H.); \\ xin.chen19960607@gmail.com (X.C.); han.dolman@vu.nl (A.J.D.) \\ 2 State Key Laboratory of Numerical Modeling for Atmospheric Sciences and Geophysical Fluid Dynamics, \\ Institute of Atmospheric Physics, Chinese Academy of Sciences, Beijing 100029, China; zeng@umd.edu \\ 3 Department of Atmospheric and Oceanic Science and Earth System Science Interdisciplinary Center, \\ University of Maryland, College Park, MD 20742, USA \\ 4 International Institute for Earth System Science, Nanjing University, Nanjing 210023, China; \\ wangjun@nju.edu.cn \\ 5 School of Applied Meteorology, Nanjing University of Information Science \& Technology, \\ Nanjing 210044, China; carolstt@gmail.com \\ 6 Department of Earth Sciences, Free University Amsterdam, 1081 HV Amsterdam, The Netherlands \\ * Correspondence: txchen@nuist.edu.cn; Tel.: 025-58695687
}

Received: 12 July 2020; Accepted: 21 August 2020; Published: 23 August 2020

\begin{abstract}
The Sahel, a semi-arid climatic zone with highly seasonal and erratic rainfall, experienced severe droughts in the 1970s and 1980s. Based on remote sensing vegetation indices since early 1980, a clear greening trend is found, which can be attributed to the recovery of contemporaneous precipitation. Here, we present an analysis using long-term leaf area index (LAI), precipitation, and sea surface temperature (SST) records to investigate their trends and relationships. LAI and precipitation show a significant positive trend between 1982 and 2016, at $1.72 \times 10^{-3} \mathrm{yr}^{-1}(p<0.01)$ and $4.63 \mathrm{~mm} \mathrm{yr}^{-1}(p<0.01)$, respectively. However, a piecewise linear regression approach indicates that the trends in both LAI and precipitation are not continuous throughout the 35 year period. In fact, both the greening and wetting of the Sahel have been leveled off (pause of rapid growth) since about 1999. The trends of LAI and precipitation between 1982 and 1999 and 1999-2016 are $4.25 \times 10^{-3} \mathrm{yr}^{-1}$ to $-0.27 \times 10^{-3} \mathrm{yr}^{-1}$, and $9.72 \mathrm{~mm} \mathrm{yr}^{-1}$ to $2.17 \mathrm{~mm} \mathrm{yr}^{-1}$, respectively. These declines in trends are further investigated using an SST index, which is composed of the SSTs of the Mediterranean Sea, the subtropical North Atlantic, and the global tropical oceans. Causality analysis based on information flow theory affirms this precipitation stabilization between 2003 and 2014. Our results highlight that both the greening and the wetting of the Sahel have been leveled off, a feature that was previously hidden in the apparent long-lasting greening and wetting records since the extreme low values in the 1980s.
\end{abstract}

Keywords: Sahel; precipitation; vegetation; sea surface temperature; greening; wetting

\section{Introduction}

The Sahel is a typical semi-arid climatic zone, located between the Sahara Desert in the North and the Sudanian Savanna in the South [1,2]. The region suffered severe droughts in the 1970s and 1980s [3,4], which had caused enormous losses and impacts. A recovery of precipitation was recorded during the 1990s and 2000s [5-9]. 
Time and space continuous vegetation indices based on satellite records became available in the early 1980s, offering long-term time series of vegetation conditions worldwide [10,11]. Several studies have demonstrated a positive trend in vegetation greenness since the early 1980s using the Normalized Difference Vegetation Index (NDVI) and, later, the leaf area index (LAI) [12-16]. Generally, in literature, "greening" refers to a statistical increase in interannual vegetation greenness indicated by vegetation indices (such as NDVI) and LAI. Currently, the global greening phenomenon and its drivers have attracted extensive research attention. Climate change, $\mathrm{CO}_{2}$ fertilization effects, land use and cover change (LUCC), and land management are the main drivers under consideration $[15,17,18]$. For typical dryland like the Sahel, precipitation enhancement (wetting) is considered the main factor affecting the greening trends [19-21] because the vegetation over the Sahel is very sensitive to precipitation variability, as water availability is the primary limiting climatic factor for vegetation growth in semi-arid environments [22-24].

The causes of droughts and the subsequent rainfall recovery in the Sahel have been massively studied from several perspectives and angles. Initially, local deforestation and overgrazing were considered to be the drivers of significant droughts during the 1970s to the 1980s [25]. Later, sea surface temperatures (SSTs) based on measurements and modelling were found to be closely related to the drying trend in the Sahel [26-28]. Several marine regions have been identified as key areas affecting the precipitation variations in the region. These include the SST gradient across the Atlantic dipole [29], the tropical Atlantic [30], the Atlantic Niño [31], the Pacific Ocean [32], and the Indian Ocean [33]. In particular, a recent study highlighted the importance of the Mediterranean Sea as a source of moisture to the Sahel as temperatures rise [34], although a non-stationary relationship between tropical SSTs and Sahelian precipitation was found $[31,35,36]$. Therefore, significant achievements have been made previously through sophisticated physical models showing that SSTs play a dominant role in the precipitation of the Sahel, although there is still much controversy in quantifying the contributions of different sea areas [36-38].

The severe droughts in the 1970s and 1980s were extreme, and present extremely low values in both the precipitation and vegetation time series. Thus, these records have a disproportionally large weight (bottom values) in their series, which leads to long-lasting greening and wetting trends in the long-term statistics. Previously, the length of the data records prevented the impact of this disproportionality to be analyzed. Now an opportunity exists to further evaluate these synergistic changes in precipitation and vegetation. Whether the strength of the greening and wetting has changed or not needs to be investigated. Meanwhile, recently developed statistical causality analysis based on Liang-Kleeman (LK) information flow theory has made benchmark progress, and it is suitable for the time series analysis of teleconnections problems [39,40]. For instance, based on the LK method, a causal relationship between greenhouse gases and global mean surface temperature anomalies was found to have reversed from the paleoclimatic period to the modern climate period (since about 1850) [41].

Therefore, involving the latest long-term data and statistical methods, the objective of this paper is to more formally establish the causal chain of changes in vegetation, precipitation, and SST in order to better understand the covariations of vegetation and climate changes in the Sahel. This is expected to provide independent statistical evidence to other physically based simulations.

\section{Materials and Methods}

\subsection{Data}

Following recent previous studies $[15,17,18], \mathrm{LAI}$ is used in this paper to indicate the vegetation conditions. LAI has two advantages at least compared to NDVI. LAI is one of the essential climatic variables (ECVs) that have clear physical meanings. Meanwhile, LAI is also the key variable in global dynamic vegetation models (DGVMs), which are widely applied in mechanism research. LAI data from the LAI3g dataset is applied; it covers the period of $1982-2016$ at a $1 / 12^{\circ}$ and $1 / 2$ month resolution [42]. A model derived from an Artificial Neural Network (ANN) was applied to AVHRR (Advanced Very 
High Resolution Radiometer) GIMMS (Global Inventory Modeling and Mapping Studies) NDVI3g to generate LAI3g [42]. In this paper, greening and browning are consistently linked to the increase and decrease in trends of the LAI, respectively, as found in previous studies.

A monthly precipitation dataset at $0.5^{\circ}$ over the period of 1901-2016 was provided by the Climatic Research Unit (CRU), version TS v4.01 [43]. SST data of the Extended Reconstructed Sea Surface Temperature (ERSST), Version 5, was used in this study at a 2-degree spatial resolution, covering the period of 1854-2016 at a monthly timescale [44].

\subsection{The Sahel Extension, Growing/Rainy Seasons, and the SST Indices}

Following previous studies, the Sahel region is defined as the rectangle area between $10^{\circ} \mathrm{N}$ and $20^{\circ} \mathrm{N}$ and between $20^{\circ} \mathrm{W}$ and $35^{\circ} \mathrm{E}$ [37,45] (Figure 1). The topography is illustrated in Figure 1a using Global 30 Arc-Second Elevation (GTOPO30) [46]. Since the boundaries of the Sahel and the Sahara in the north are not simple straight lines, only the vegetal area of this rectangle region is selected. Each $0.5^{\circ} \times 0.5^{\circ}$ cell presents a vegetation cover (LAI $>0$ ) of no less than $50 \%$ (Figure $1 \mathrm{~b}$ ). Considering that the precipitation in this area has a larger gradient in the north-south direction, the region with an average annual precipitation of no more than $800 \mathrm{~mm}$ during the 30 years from 1987-2016 is selected.
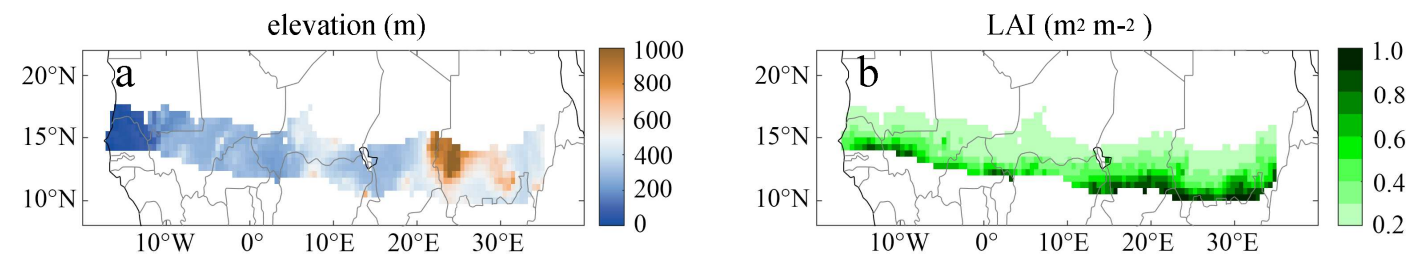

Figure 1. The spatial extension of the Sahel. (a) Topography. The DEM (Digital Elevation Model) of GTOPO30 data is used; (b) annual averaged leaf area index (LAI) based on Global Inventory Modeling and Mapping Studies (GIMMS) LAI3g dataset between 1982 and 2016.

Due to the delayed response of vegetation changes to the water availability, the maximum value of LAI appears in September, which is one month behind the August extreme of precipitation (Figure 2a,b). Vegetation growth is concentrated in the rainy season due to the limitation of water availability. A $0.5 \mathrm{~m}^{2} \mathrm{~m}^{-2} \mathrm{LAI}$ threshold was used to determine the growing period of vegetation, i.e., June to November $(\mathrm{J}-\mathrm{N})$. Precipitation from May to October $(\mathrm{M}-\mathrm{O})$ was further selected as the rainy season for the study, which is consistent with a previous study [7], and this is one month ahead of the growing period. As indicated by the precipitation seasonal cycle, the Sahel typically has a dry and a wet season. The total rainfall from November to March is less than $10 \mathrm{~mm}$ (Figure 2b). Between 1982 and 2016, the precipitation of the rainy season (M-O) accounts for more than $97.2 \%$ of the total annual precipitation $(627.1 \mathrm{~mm}$ versus $645.1 \mathrm{~mm}$ ). During the rainy and dry season, the LAI also shows typical seasonal variations following precipitation.

Previous studies have identified several key SST regions corresponding to Sahelian precipitation $[7,30,31]$. The SST index is generated by the regional SSTs or a combination thereof. Table 1 summarizes these SST indices, including their spatial expansions and descriptions $[7,31,36]$. The averages from May to October (M-O) are used to calculate the annual time series in analyzing the relationship between precipitation and SST.

The SST difference between subtropical North Atlantic and global tropical oceans has been suggested previously to resolve a disagreement in the projection of Sahelian precipitation [7]. One recent study [34] suggested that the Mediterranean Sea plays an important role in the Sahel's rainfall recovery through moisture supply [38]. The SST index proposed here considers these three regions above with the aims to improve the coherence of interannual variations between regional SSTs and the Sahelian precipitation and is a linear combination of the SSTs of the Mediterranean Sea, the subtropical North Atlantic, and the global tropical oceans, denoted as MAG (Table 1). 
Table 1. List of sea surface temperature (SST) indices evaluated in this paper and interannual correlations (r) between these indices and the Sahelian precipitation averaged over May to October (M-O) between 1901 and 2016, including the one proposed in this study - a linear combination of the Mediterranean Sea, the subtropical North Atlantic, and the global tropical oceans.

\begin{tabular}{|c|c|c|c|c|c|}
\hline NO. & SST Index & $\begin{array}{c}\text { Spatial } \\
\text { Extension }\end{array}$ & Comments & $r(1901-2016)$ & $r(1982-2016)$ \\
\hline 1 & Atln3 & $\begin{array}{l}3^{\circ} \mathrm{S}-3^{\circ} \mathrm{N} \\
15^{\circ} \mathrm{W}-0^{\circ} \mathrm{W}\end{array}$ & Atlantic Nino 3 & $-0.29 * *$ & 0.20 \\
\hline 2 & Atn & $\begin{array}{l}10^{\circ} \mathrm{N}-40^{\circ} \mathrm{N} \\
75^{\circ} \mathrm{W}-15^{\circ} \mathrm{W}\end{array}$ & $\begin{array}{l}\text { subtropical North } \\
\text { Atlantic }\end{array}$ & 0.07 & $0.59 * *$ \\
\hline 3 & Attn & $\begin{array}{l}10^{\circ} \mathrm{N}-25^{\circ} \mathrm{N} \\
75^{\circ} \mathrm{W}-15^{\circ} \mathrm{W}\end{array}$ & $\begin{array}{l}\text { tropical North } \\
\text { Atlantic }\end{array}$ & -0.07 & $0.46^{* *}$ \\
\hline 4 & Atts & $\begin{array}{l}20^{\circ} \mathrm{S}-10^{\circ} \mathrm{N} \\
75^{\circ} \mathrm{W}-15^{\circ} \mathrm{E}\end{array}$ & $\begin{array}{l}\text { tropical South } \\
\text { Atlantic }\end{array}$ & $-0.26^{* *}$ & 0.27 * \\
\hline 5 & Att & $\begin{array}{l}20^{\circ} \mathrm{S}-20^{\circ} \mathrm{N} \\
75^{\circ} \mathrm{W}-15^{\circ} \mathrm{E}\end{array}$ & tropical Atlantic & $-0.20^{* *}$ & 0.38 \\
\hline 6 & Med & $\begin{array}{c}30^{\circ} \mathrm{N}-50^{\circ} \mathrm{N} \\
0^{\circ}-50^{\circ} \mathrm{E}\end{array}$ & Mediterranean Sea & $0.32 * *$ & $0.70 * *$ \\
\hline 7 & GT & $\begin{array}{c}20^{\circ} \mathrm{S}-20^{\circ} \mathrm{N} \\
180^{\circ} \mathrm{W}-180^{\circ} \mathrm{E}\end{array}$ & $\begin{array}{c}\text { global tropical } \\
\text { oceans }\end{array}$ & $-0.27^{* *}$ & 0.20 \\
\hline 8 & Nino3 & $\begin{array}{l}90^{\circ} \mathrm{W}-150^{\circ} \mathrm{W} \\
5^{\circ} \mathrm{S}-5^{\circ} \mathrm{N}\end{array}$ & Pacific Nino 3 & $-0.28^{* *}$ & -0.29 \\
\hline 9 & Atd1 & Atn minus GT & $\begin{array}{c}\text { The difference } \\
\text { between subtropical } \\
\text { North Atlantic and } \\
\text { global tropics } \\
\text { The difference }\end{array}$ & $0.51 * *$ & $0.60^{* *}$ \\
\hline 10 & Atd2 & $\begin{array}{c}\text { Attn minus } \\
\text { Atts }\end{array}$ & $\begin{array}{c}\text { between tropical } \\
\text { North and South } \\
\text { Atlantic }\end{array}$ & $0.32 * *$ & 0.28 \\
\hline 11 & $\mathrm{MAG}^{\mathrm{a}}$ & $\begin{array}{c}\text { Med } \times \alpha+\text { Atn } \\
\times \beta-G T \times \lambda\end{array}$ & $\begin{array}{l}\text { Linear combination } \\
\text { of Atn, GT and Med }\end{array}$ & $0.65^{* *}$ & $0.72 * *$ \\
\hline
\end{tabular}

Note. a $\alpha=2.3328 ; \beta=1.8727 ; \lambda=-5.2055$. * indicates $p<0.1,{ }^{* *}$ indicates $p<0.01$. MAG: linear combination of the SSTs of the Mediterranean Sea, the subtropical North Atlantic, and the global tropical oceans. 

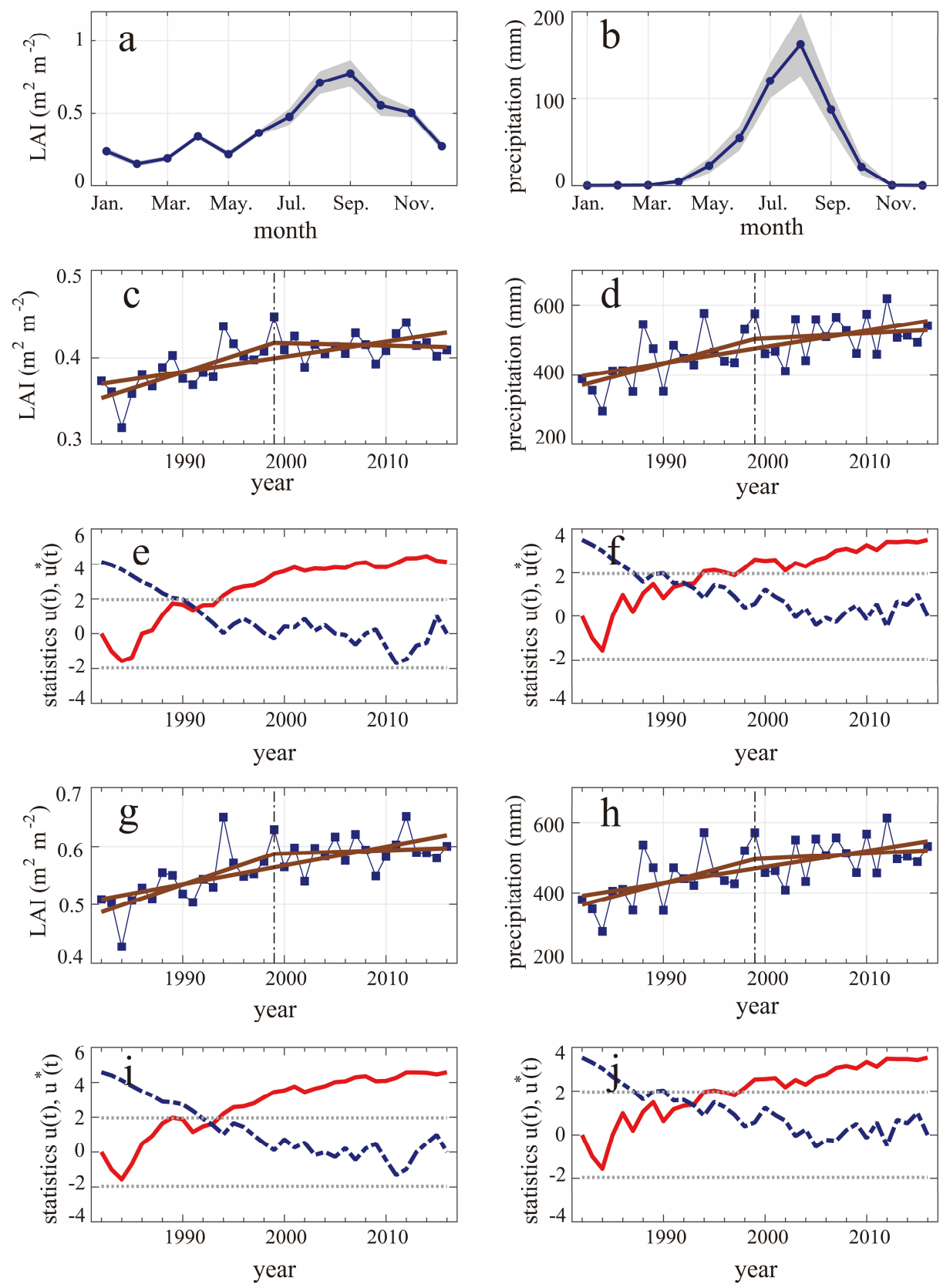

Figure 2. Time series of LAI and precipitation between 1982 and 2016. (a-b) Seasonal patterns of LAI and precipitation based on the annual averages between 1982 and 2016. Blue curves are the averages of each month with standard deviations indicated by grey areas. (c-d) Interannual time series (blue curves with squares) with corresponding linear fit between 1982 and 2016 and piecewise linear regression (PLR) analysis fits, using 1999 at the turning point. (e-f) Mann-Kendall-Sneyers MKS analysis of annual LAI and precipitation between 1982 and 2016 with forward $\left(u_{k}\right.$, red line) and backward $\left(u_{k}^{*}\right.$, blue dashed line). (g-j) Similar to (c-f) but using June to November (J-N) LAI and May to October $(\mathrm{M}-\mathrm{O})$ precipitation instead.

\subsection{Trend Analysis}

A non-parametric Mann-Kendall test is applied to determine the significance of the trends. To investigate the coherence and the variation of trends in the LAI, precipitation, and SST, two methods were applied: the non-parametric Mann-Kendall-Sneyers (MKS) and a piecewise linear regression (PLR) approach. 
The non-parametric MKS method [47-49] is widely used to assess change trends in hydrological and meteorological time series [50]. For an $\mathrm{n}$ length time series $x_{1}, \ldots, x_{\mathrm{n}}$, for each element $x_{\mathrm{i}}$, the corresponding preceding number $m_{\mathrm{i}}$ is given by

$$
m_{i}=\sum_{j=1}^{i} r_{j} r_{j}=\left\{\begin{array}{ll}
1 & x_{i}>x_{j} \\
0 & x_{i} \leq x_{j}
\end{array}(j=1,2,3, \ldots, i)\right.
$$

A statistical variable is then defined as

$$
s_{k}=\sum_{i=1}^{k} m_{k}(1 \leq k \leq n)
$$

with the mean and variance given by

$$
\begin{gathered}
E\left(s_{k}\right)=\frac{k(k-1)}{4} ; \operatorname{var}\left(s_{k}\right)=\frac{k(k-1)(2 k+5)}{72} \\
u_{k}=\left(s_{k}-E\left(s_{k}\right)\right) / \sqrt{\operatorname{var}\left(s_{k}\right)}
\end{gathered}
$$

Under the null hypothesis (no trend), $u_{k}$ is normally distributed. A two-tailed significance test is used at the significant level $\alpha$ (here $\alpha=0.05$, and the confidence interval \pm 1.96 ) if $\left|\left(u_{k}\right)\right| \leq\left(u_{k}\right) 1-\alpha / 2$, where $\left(u_{k}\right) 1-\alpha / 2$ is the critical value of the standard normal distribution. An increasing or decreasing trend is indicated by $u_{k}>0$ or $u_{k}<0$, respectively. A similar analysis is applied on the backward time series to get the statistics $u^{*}$. An abrupt change of the trends could be detected by the intersection point of $u_{k}$ and $u^{*}{ }_{k}$ within the confidence interval [51,52].

The PLR approach $[53,54]$ is also called segmented linear regression. A significance test can then be applied to determine the reasonableness of segmentation. A linear regression approach was applied to each successive two interval segments to test the turning-point significance by a t-test against the null hypothesis. This model is given by

$$
Y= \begin{cases}\beta_{0}+\beta_{1} X+\varepsilon & X \leq \alpha \\ \beta_{0}+\beta_{1} X+\beta_{2}(X-\alpha)+\varepsilon & X>\alpha\end{cases}
$$

where $X$ is time and $Y$ is the LAI, precipitation, or SST indices. A t-test was applied to test if $\beta_{2}$ is not equal to zero. The turning points are confined within the period of 1994-2003 in order to avoid too few records in either segment of the time series. Be aware that the slopes of the PLR methods ( $\beta_{1}$ and $\beta_{1}+\beta_{2}$ ) are different from the slopes directly calculated before and after the turning point because the continuity of the turning point in the PLR method is maintained.

\subsection{Teleconnection Analysis between SST and Precipitation}

From the perspective of mechanism and observational analysis, the Sahel is a typical semi-arid region, and vegetation growth is thus strongly constrained by water availability, which is visible in the regional average and spatial patterns of vegetation and precipitation. However, for SST and precipitation, the relationship is different and acts through teleconnections. These are more difficult to analyze simply from the correlation perspective. While correlation analysis is key to explaining the similarity in the variability of two events, it does not bear the needed asymmetry to imply causality, that is, to distinguish which event is the driver and which is the effect. Hence, a dynamic causality formalism capable of handling non-stationary time series to analyze the causal structure of the SST on 
the Sahelian precipitation is needed. Hagan et al. [40] proposed that given any two time series, $X_{1}$ and $X_{2}$, the time-varying information from $X_{2}$ to $X_{1}$ at each time step, $T_{2 \rightarrow 1_{t}}$, can be computed as

$$
T_{2 \rightarrow 1_{t}}=\frac{P_{12}}{P_{11}} \bullet \frac{-P_{12} P_{1, d 1}+P_{11} P_{2, d 1}}{P_{11} P_{22}-P_{12}^{2}}
$$

where $P_{i j}$ is the covariance at each time step between $X_{i}$ and $X_{j}$ derived with a Kalman filter, and $P_{i}, d_{j}$ is the covariance at each time step between $X_{i}$ and $X_{d j}$, given that $X_{d j}=\left[X_{j}(t+k \Delta t)-X_{j}(t)\right] /(k \Delta t)$. $\Delta t$ represents the change in timestep, and $k$ represents an integer. A statistically significant information flow in $T_{2 \rightarrow 1_{t}}$ suggests that the evolution of $X_{1}$ is, to an extent, dependent on $X_{2}$. Where it is positive, $X_{2}$ makes $X_{1}$ more uncertain, and where it is negative, $X_{2}$ stabilizes $X_{1} . T_{2 \rightarrow 1}$ becomes essentially 0 where $X_{1}$ is non-causal to $X_{2}$. For more details on this formalism that is based on information flow theory and provides a robust bidirectional causality analysis, readers are referred to [39,40].

\section{Results}

\subsection{Coherent Trends of the LAI and Precipitation}

The greening in the Sahel is evident in the LAI time series. As illustrated in Figure 2, both annual and J-N LAI have increased significantly between 1982 and 2016 at rates of $1.72 \times 10^{-3} \mathrm{yr}^{-1}(p<0.01)$ and $3.23 \times 10^{-3} \mathrm{yr}^{-1}(p<0.01)$, respectively. With 1982 as the starting point for the time series, LAI has increased significantly since about 1990 indicated by the line of $u_{k}$ and the intersection point of $u_{k}$ and $u^{*}$ in Figure $2 \mathrm{e}, \mathrm{i}$.

Intuitively, the vegetation did not maintain a steady growth rate during the whole period. Based on the PLR analysis on annual LAI, $\beta_{2}$ is significant $(p<0.01)$ for all the years between 1994 and 2003. The year of 1999 was selected as the typical turning point because the LAI was the largest in 1999 between 1994 and 2003, and 1999 also happens to be the middle point of the study period of 1982-2016. The LAI interannual trends between 1982 and 1999 and $1999-2016$ were $4.25 \times 10^{-3}$ and $-0.27 \times 10^{-3}$, respectively (Table 2$)$. The year 1999 is a significant $(p<0.01)$ turning point of both the annual and J-N LAI time series (Table 2). $\mathrm{R}^{2}$ increases from 0.45 to 0.60 (annual) and from 0.50 to 0.58 (J-N) from linear and PLR regressions (Table 2). Therefore, although vegetation continued to green throughout 1982-2016, the greening trend has been leveled off (pause of rapid growth) since about 1999.

Table 2. PLR analysis of LAI, precipitation, and SST indices between 1982 and 2016 with turning point (TP) at 1999. The coefficient of determination $R^{2}$ indicates the linear regression and PLR regressions of the time series between 1982 and 2016. $\beta_{1}$ and $\beta_{2}$ are the regression coefficients of the PLR method.

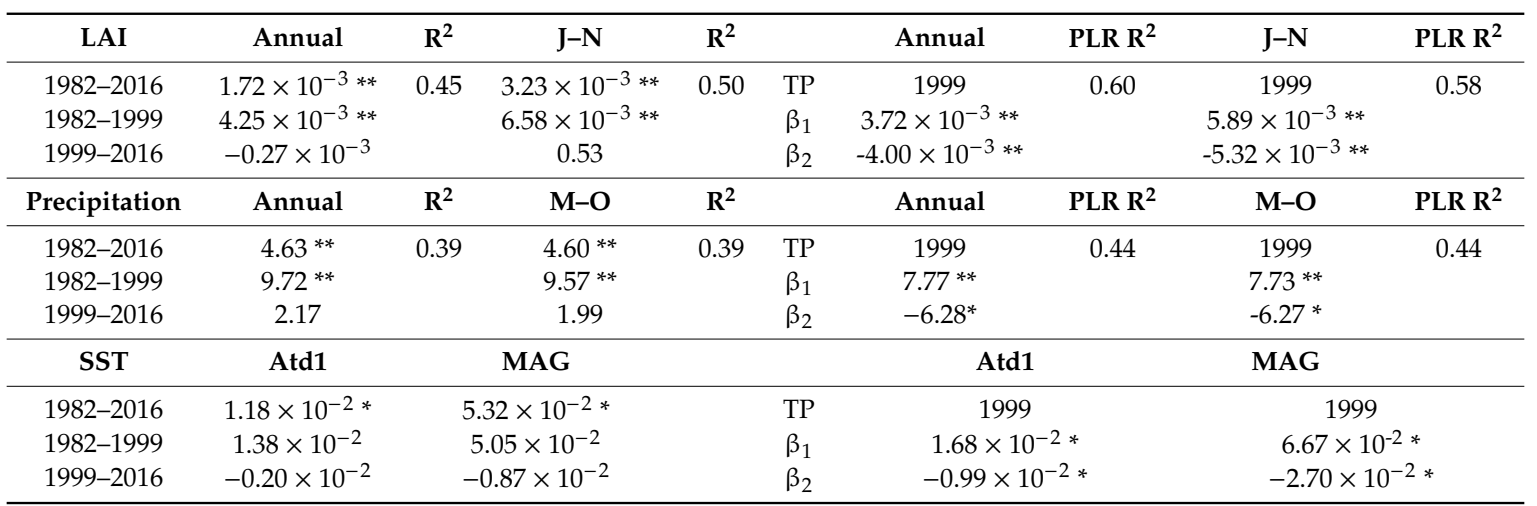

Note: The units of LAI, precipitation and SST trends are $\mathrm{m}^{2} \mathrm{~m}^{-2} \mathrm{yr}^{-1}, \mathrm{~mm} \mathrm{yr}^{-1}$, and ${ }^{\circ} \mathrm{C} \mathrm{yr}^{-1}$, respectively. ${ }^{*}$ indicates $p<0.1,{ }^{* *}$ indicates $p<0.01$.

Precipitation is usually considered as the primary driver of the vegetation dynamics. An upswing of rainfall in the Sahel occurred after the severe drought occurrences of the 1970s and 1980s. According to the records, the rainfall in the Sahel reached a historic low in 1984. As shown in Figure 2d,h, both annual 
and M-O precipitation increased significantly between 1982 and 2016 at the rates of $4.63 \mathrm{~mm} \mathrm{yr}^{-1}$ $(p<0.01)$ and $4.60 \mathrm{~mm} \mathrm{yr}^{-1}(p<0.01)$. With 1982 as the starting point for the time series, precipitation increased significantly started at about 1994, indicated by the line of $u_{k}$ Figure $2 \mathrm{f}, \mathrm{j}$.

However, we notice that the trend of rainfall recovery is also unstable in time. As we have done with the LAI records, the PLR method is also applicable to precipitation time series with turning points ranging from 1994 to 2003. $\beta_{2}$ is significant $(p<0.1)$ for turning points between 1994 and 1999 for both annual and M-O time series. Taking again 1999 as the typical turning point, the change in the annual precipitation in these two adjacent periods is $9.72 \mathrm{~mm} \mathrm{yr}^{-1}$ and $2.17 \mathrm{~mm} \mathrm{yr}^{-1}$, respectively (Table 2), and $9.57 \mathrm{~mm} \mathrm{yr}^{-1}$ and $1.99 \mathrm{~mm} \mathrm{yr}^{-1}$ for M-O precipitation. Compared with the LAI, which changes from increasing to slightly decreasing, precipitation still maintained a slight upward trend between 1999 and 2016. The pause of rapid growth in precipitation still suggests that the wetting has leveled off since about 1999.

Therefore, both the LAI and precipitation have shown relatively consistent changes between 1982 and 2016. Starting from 1982, they all maintained a statistically significant upward trend from the early 1990s to 2016. However, both LAI and precipitation have been leveled off since 1999 statistically.

The spatial pattern of trends based on the PLR analysis is shown in Figure 3. The year 1999 was used as the typical turning point. From 1982 to 1999 , greening $(85.0 \%$ and $63.8 \%$ with $p<0.1)$ and wetting $(100 \%$ and $80.0 \%$ with $p<0.1)$ dominated the Sahel. Such increasing trends are more obvious between 1982 and 1999 compared to 1982-2016, when greening and wetting accounted for 93\% and 100\% (all are significant). However, between 1999 and 2016, both the LAI and precipitation leveled off. Based on the PLR analysis, 1999 was identified as a significant turning point for $96.7 \%$ of the areas with LAI trends, and for all precipitation grids. The greening and wetting grids decreased to $42.2 \%$ and $67 \%$. In fact, large browning and drying areas are also observed (54.4\% and 32.9\%) (Figure 3).
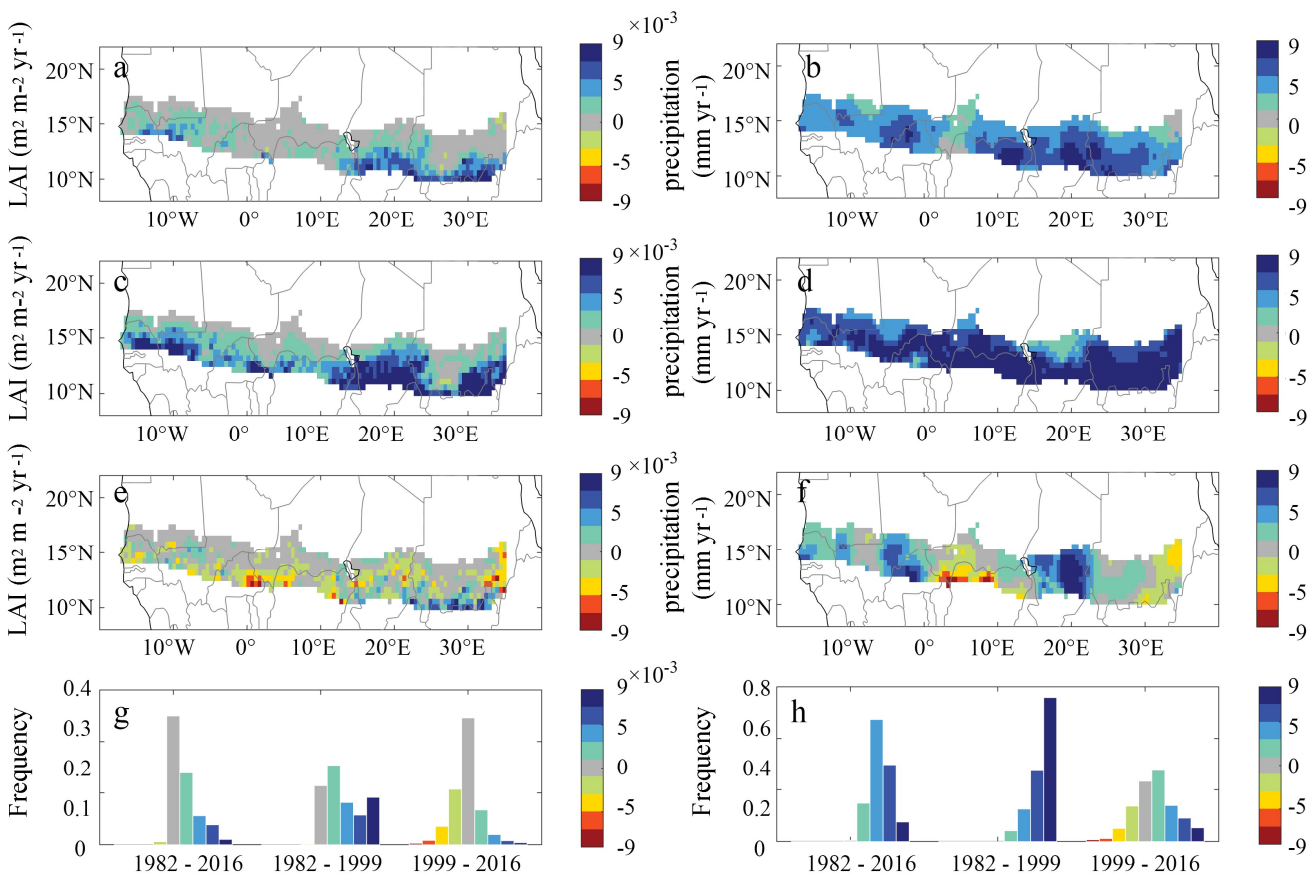

Figure 3. Grid trends (per year) of LAI $\left(\mathrm{m}^{2} \mathrm{~m}^{-2} \mathrm{yr}^{-1} \times 10^{-3}\right)$ and precipitation $\left(\mathrm{mm} \mathrm{yr}^{-1}\right)$ during the two periods divided by the turning point in 1999. (a-b) LAI and precipitation annual trend during the whole study period 1982-2016. (c-d) Corresponding trend for the period of 1982-1999. (e-f) Annual trend between 1999 and 2016. (g-h) The frequency distributions of corresponding trends of the LAI and precipitation. 


\subsection{The Relationship between SST Indices and Precipitation}

As shown above, interannual variation in vegetation of the Sahel is driven primarily by precipitation. The actual physical mechanism of interannual variation of precipitation is complicated, but generally the main controlling factor is the SST. As described in the previous method section, this paper uses a new SST index MAG based on the key areas studied by previous researchers.

MAG better characterizes the impact of oceans on the Sahelian precipitation between 1901 and 2016 than any of the other SST indicators (Table 1), with a significant correlation coefficient (r) of 0.65 $(p<0.01)$ between 1901 and 2016 and $0.72(p<0.01)$ between 1982 and 2016. We also calculated the correlation coefficients for the other 10 SST indices. The index proposed by Giannini [7] has the highest r of 0.51 within these 10 indices between 1901 and 2016, although it is still lower than that of MAG (Table 1).

The correlation coefficients for 1901-2016 show the general relationship between SST index and the Sahelian precipitation. It is interesting to note that, although previous studies have illustrated a non-stationary relationship between tropical SST and the Sahelian precipitation [31,36], MAG exhibits a rather stationary relationship with the Sahelian rainfall. As shown in Figure 4, similar to previous studies, a 20 year sliding window running correlation analysis between 1901 and 2016 was used between the SST indices and Sahelian precipitation. The non-stationary relationship between tropical SST and the Sahelian precipitation claimed before is also quite clear. However, the situation changes once the Mediterranean SST is also considered. The correlation between MAG and Sahel rainfall ranges from 0.22 to 0.76 and is $0.54 \pm 0.11$ using a 20 year sliding window. Of the 97 values, 89 are significant $(p<0.1)$, accounting for $91.1 \%$.

Whether SST is responsible for the Sahelian precipitation trend changes at about 1999 as shown above is now further investigated. The anomalies of precipitation and SST indices between 1982 and 2016 are illustrated in Figure 5a. The time-dependent information flow (IF) from three of the SST indices to the Sahelian precipitation is shown in Figure 5b, and is computed from Equation (6) (see Data and Method). The IFs using the other 8 SST indices are not shown due to insignificant results. The broken lines indicate the evolution of the IF, and the solid lines indicate the statistically significant periods of the IF. Since 1999, all IFs of the three SST indices are negative. Both Med and Atd1 have some significant negative IFs between 2003 and 2014. At the same time, better performance appears on the MAG index with all significant negative IFs between 2003 and 2014. This implies that, within this period, the SST anomalies have contributed to the stabilizing or leveling off of the precipitation in the Sahel. While a positive IF would indicate that SST anomalies function to make the precipitation either increase or decrease, the negative IF here suggests that the evolution of SST anomalies keeps the precipitation around a long-term constant mean; that is, it levels it off. Quantitatively, this is most clearly seen in the IF of the MAG. This suggests that these are important sources of information for understanding the Sahelian precipitation variability. It is important to note here that the direction of impact is implied in the IF obtained, so this represents the real causality of the SST interannual variations with respect to that of the Sahelian precipitation [39]. 


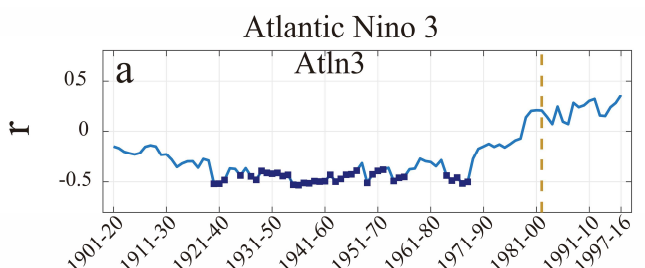

tropical North Atlantic

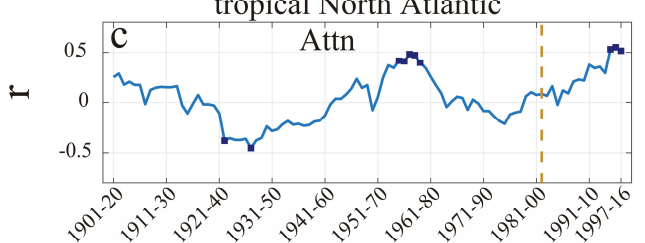

tropical Atlantic

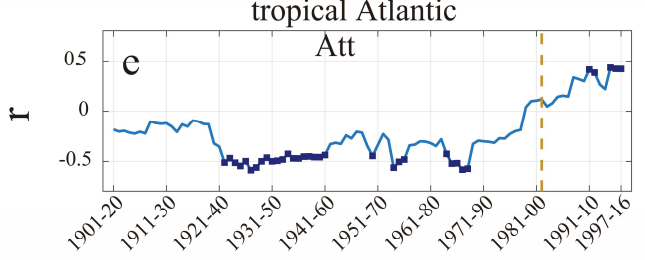

global tropical oceans

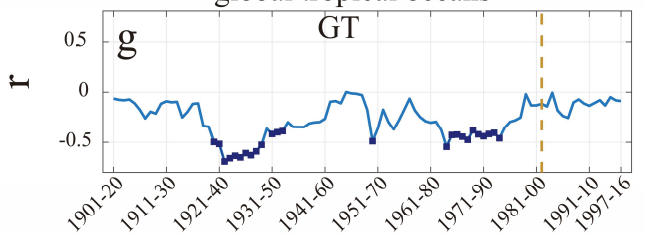

The difference between subtropical North Atlantic and global tropics
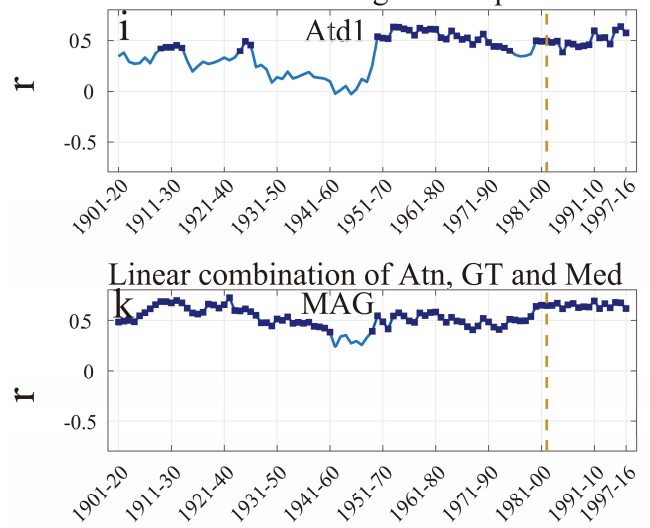

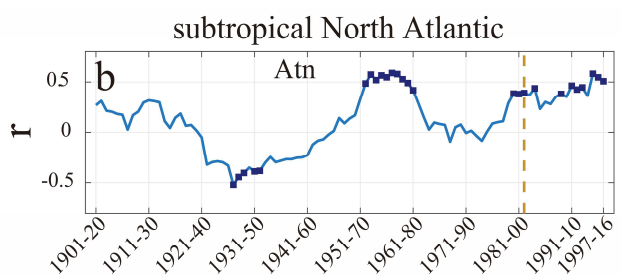

tropical South Atlantic
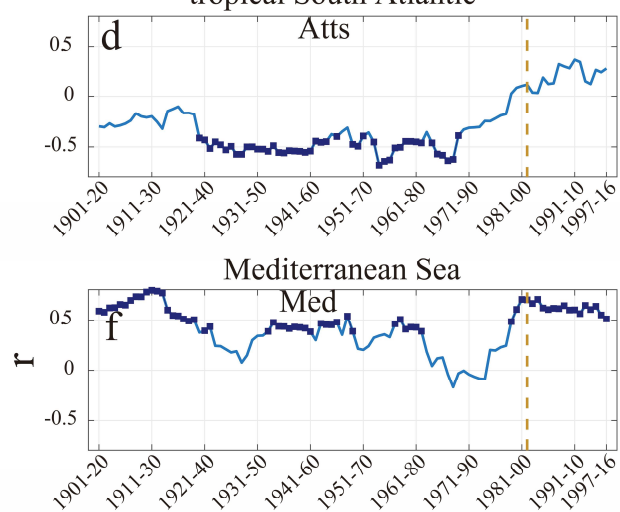

Pacific Nino 3

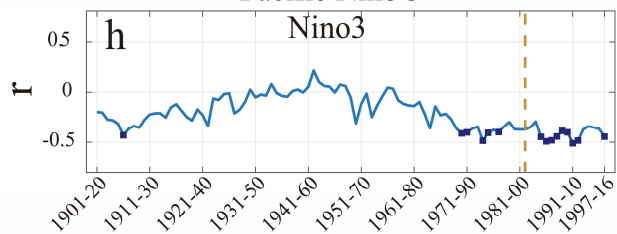

The difference between tropical North and South Atlantic

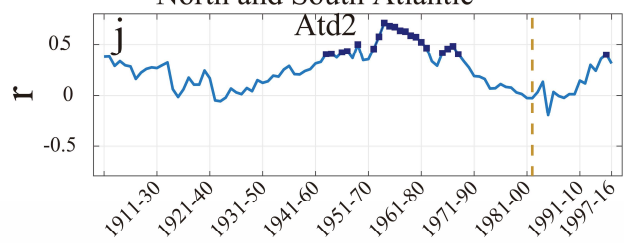

Figure 4. A 20 year sliding window running correlation between M-O SSTs and Sahel precipitation. Significant values $(p<0.1)$ of the correlation in the 20 year windows are indicated with a dot symbol. 

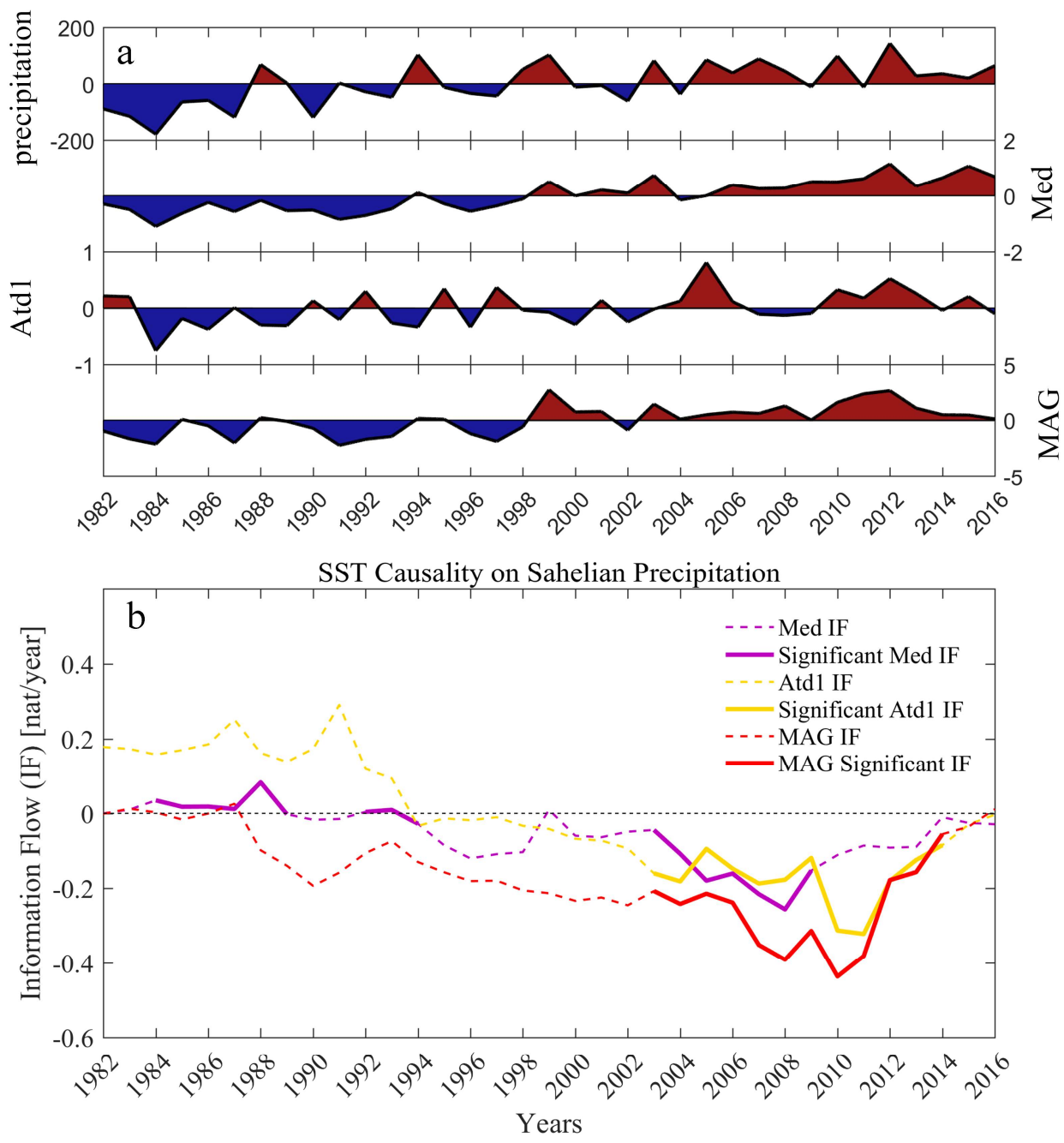

Figure 5. Anomalies and information flow. (a) Annual anomalies of M-O precipitation-Med, Atd1, and MAG between 1982 and 2016. (b) The information flow from three M-O SST indices-Med (purple), Atd1 (yellow), and MAG (red) — to the Sahelian precipitation from 1982 to 2016. Solid lines represent statistically significant values which imply causality. Missing values at the beginning are due to the Kalman filter computation, where earlier values are used to forecast latter values.

\section{Discussion}

Significant greening and wetting trends existed in the Sahel between 1982 and 2016. However, due to the extreme drought of the 1980s, the weight of this period in the time series affected the overall trends disproportionally. Long-term continuous vegetation data of 35 years provides the opportunity to examine whether trends have really changed. Based on the PLR methods, significant turning points have been detected in both the LAI and precipitation time series. Taking the year of 1999 as the typical turning point, greening and wetting trends have leveled off. Such changes are also clearly expressed in the spatial patterns (Figure 3). Even considerable browning areas are found due to the drying trends between 1999 and 2016. Although overall both greening and wetting have leveled off, precipitation is still slightly increasing, and vegetation has begun to decline slightly. Several potential mechanisms have been considered to account for this phenomenon. Changes in surface water balance are caused by temperature changes, which may not be fully reflected in changes in precipitation. Secondly, human activities in this area are intense. Although quantifying the contribution and impact of human activities has always been an unresolved problem, previous studies have long realized this.

These statistics-based results largely depend on the accuracy of the data. Previous studies have shown that deviations exist among the vegetation indices of different satellite sources [42]. Meanwhile, 
the low density of site measurements also affects the quality of the precipitation data in the area. We addressed this issue by comparing LAI3g and Moderate Resolution Imaging Spectroradiometer (MODIS) LAI products (MOD15A2H, V006) [55] and comparing CRU data with remotely sensed precipitation (TRMM, Tropical Rainfall Measuring Mission) [56], which has the advantage of coverage (Table 3).

Table 3. Trend analysis of the LAI between 2001 and 2016 and precipitation of 1999-2016 from different sources.

\begin{tabular}{cccccc}
\hline 2001-2016 & Annual & J-N & 1999-2016 & Annual & M-O \\
\hline GIMMS LAI3g & $0.38 \times 10^{-3 * *}$ & $1.08 \times 10^{-3 * *}$ & CRU Precipitation & $2.17^{* *}$ & $1.99 * *$ \\
MODIS LAI & $1.69 \times 10^{-3 * *}$ & $1.88 \times 10^{-3 * *}$ & TRMM Precipitation & $1.33^{* *}$ & $1.26^{* *}$ \\
\hline
\end{tabular}

Note. The units of LAI and precipitation trends are $\mathrm{m}^{2} \mathrm{~m}^{-2} \mathrm{yr}^{-1}$ and $\mathrm{mm} \mathrm{yr}^{-1}$, respectively. CRU: Climatic Research Unit, TRMM: Tropical Rainfall Measuring Mission. ${ }^{* *}$ indicates $p<0.01$.

As illustrated in Figure 6 and Table 3, the seasonal variations between LAI3g and MODIS-LAI and between CRU and TRMM precipitation are very similar. MODIS-LAI had a higher positive trend at $1.69 \times 10^{-3} \mathrm{yr}^{-1}$ than that of LAI3g at $0.38 \times 10^{-3} \mathrm{yr}^{-1}$ between 2001 and 2016; however, this trend of MODIS-LAI is still less than half of the trend of LAI3g between 1982 and 1999 at $4.25 \times 10^{-3}$. Meanwhile, the trend of TRMM precipitation was lower than that of CRU records (Table 3), which indicates that the wetting may level off in a stronger way. In addition, the spatial patterns of the changes between these datasets were also generally consistent (Figure 7), although TRMM precipitation has more areas with negative trends in the middle of the Sahel (Figure 7d). This suggests that the results found above could be maintained across different datasets.

Until the middle of 2020, papers about the Sahel greening (or re-greening) and its mechanism were published every month, as suggested by Google Scholar when the term "greening Sahel" is used. Some work, although not much, has begun to investigate the turning points of dryland ecosystems [57]. Due to the intensive human activities and land-atmosphere interactions, the mechanisms of ecosystems change are still under study. The findings of this paper suggest that the different stages of vegetation changes should be considered.

In water-limited regions, the response of vegetation growth to precipitation is relatively evident. A broader perspective could be expected if the drivers of precipitation can be determined. Here, we developed a new SST index, MAG, by using SSTs from three ocean areas, including the Mediterranean Sea, the subtropical North Atlantic, and global tropical oceans. Although MAG is based on statistical fit, the three selected regions are based on key areas identified by previous studies [7,34], rather than on a random basis. In order to avoid a result that is generated fortuitously, we further arranged the above eight independent sea areas (thus not including Atd1 and Atd2) with all the combinations in groups of three. The number of three-combinations of eight elements is equal to 56 . Thus, 56 correlation coefficients (not shown) were obtained with precipitation time series. The maximum correlation in this set still appears in the MAG combination. Therefore, this index identifies three key SST areas that affect precipitation in the Sahel. MAG is found to be closely related to Sahel precipitation on an interannual scale, and the relationship between these is found to be stable in time based on a 20 year sliding window running correlation analysis. Application of a causality analysis further revealed that, in recent years, these SST indices become a source of stability (equilibrium) for the Sahelian precipitation, with the MAG being the most significant driver of the variability, although it is important to note that changes in SST may be either natural or have an anthropogenic signature $[34,58]$. 

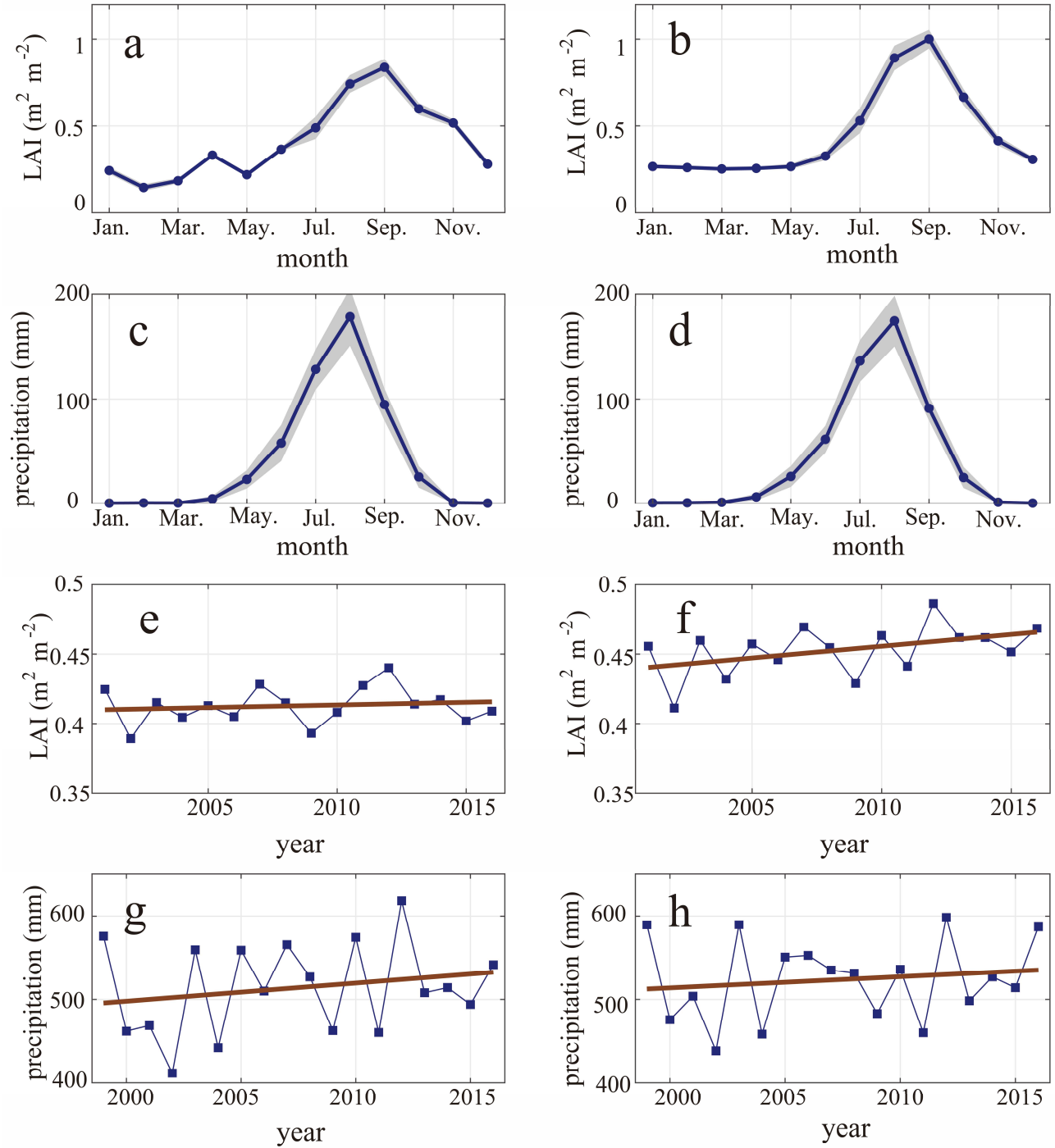

Figure 6. Time series of LAI and precipitation. (a-d) Blue curves are the averages of each month with standard deviations indicated by grey areas. (e-h) Interannual time series (blue curves with squares). (a,e) The GIMMS LAI3g from 2001 to 2016. (b,f) The MODIS LAI from 2001 to 2016. (c,g) The CRU precipitation from 1999 to 2016. (d,h) The TRMM 3B43 precipitation from 1999 to 2016.
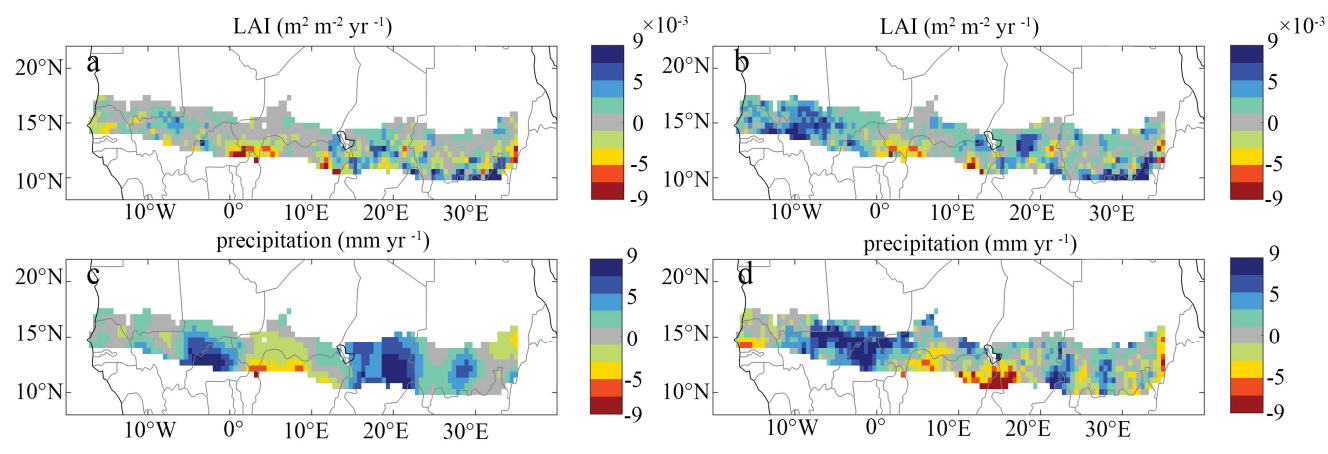

Figure 7. Grid trends (per year) of LAI $\left(\mathrm{m}^{2} \mathrm{~m}^{-2} \mathrm{yr}^{-1} \times 10^{-3}\right)$ from 2001 to 2016 and precipitation $\left(\mathrm{mm} \mathrm{yr}^{-1}\right.$ ) from 1999 to 2016. (a) The GIMMS LAI3g. (b) The MODIS LAI. (c) The CRU precipitation. (d) The TRMM 3B43 precipitation. 


\section{Conclusions}

In conclusion, the semi-arid Sahel still shows small greening and wetting trends between 1982 and 2016. Based on a piecewise linear regression analysis, both the greening and the wetting of the Sahel have been leveled off since about 1999 in both regional averaged and gridded records.

Even some browning areas are found due to the drying trends between 1999 and 2016. The differences between the trends of the whole period and segments are mainly due to the extremely low records during the severe drought in the early 1980s. The SST index present here, MAG, by considering the Mediterranean Sea, the subtropical North Atlantic, and the global tropical oceans, could explain the stable station of precipitation since about 2003. Therefore, the levelling off of the greening is a response to precipitation changes affected by the SST. Our analysis shows furthermore that care needs to be taken when analyzing climate records that have decadal trends that show extreme values. These may disproportionally affect the causal structure of the variability.

Author Contributions: Conceptualization, T.C., N.Z. and A.J.D.; Data curation, S.Z. and X.C.; Methodology, T.C., C.L. and D.F.T.H.; Software, S.Z. and C.L.; Supervision, N.Z. and A.J.D.; Validation, T.C.; Visualization, S.Z., C.L. and X.C.; Writing-original draft, T.C., J.W., T.S. and A.J.D.; Writing-review and editing, T.C., T.S. and A.J.D. All authors have read and agreed to the published version of the manuscript.

Funding: This research received no external funding.

Acknowledgments: This research was supported by the National Key R\&D Program of China (NO. 2017YFB0504000), the National Natural Science Foundation of China (NO. 31570464, 41561124014, 41375099, 41605039), the NUIST research startup fund (NO. 2241021301065 and 2241051301004), and the Natural Science Foundation for Young Scientists of Jiangsu Province, China (grant no. BK20160625). A.J. Dolman acknowledges support from the program of the Netherlands Earth System Science Centre (NESSC), financially supported by the Ministry of Education, Culture and Science (OCW) (grant 024.002.001).

Conflicts of Interest: The authors declare no conflict of interest.

\section{References}

1. Kottek, M.; Grieser, J.; Beck, C.; Rudolf, B.; Rubel, F. World map of the Koppen-Geiger climate classification updated. Meteorol. Z. 2006, 15, 259-263. [CrossRef]

2. Peel, M.C.; Finlayson, B.L.; McMahon, T.A. Updated world map of the Koppen-Geiger climate classification. Hydrol. Earth Syst. Sci. 2007, 11, 1633-1644. [CrossRef]

3. Dai, A.; Lamb, P.J.; Trenberth, K.E.; Hulme, M.; Jones, P.D.; Xie, P. The recent Sahel drought is real. Int. J. Climatol. 2004, 24, 1323-1331. [CrossRef]

4. Held, I.M.; Delworth, T.L.; Lu, J.; Findell, K.L.; Knutson, T.R. Simulation of Sahel drought in the 20th and 21st centuries. Proc. Natl. Acad. Sci. USA 2005, 102, 17891-17896. [CrossRef]

5. Ali, A.; Lebel, T. The Sahelian standardized rainfall index revisited. Int. J. Climatol. 2009, 29, $1705-1714$. [CrossRef]

6. Biasutti, M. Rainfall trends in the African Sahel: Characteristics, processes, and causes. Wiley Interdiscip. Rev. Clim. Chang. 2019, 10, e591. [CrossRef]

7. Giannini, A.; Salack, S.; Lodoun, T.; Ali, A.; Gaye, A.T.; Ndiaye, O. A unifying view of climate change in the Sahel linking intra-seasonal, interannual and longer time scales. Environ. Res. Lett. 2013, 8, 024010. [CrossRef]

8. Hagos, S.M.; Cook, K.H. Ocean warming and late-twentieth-century Sahel drought and recovery. J. Clim. 2008, 21, 3797-3814. [CrossRef]

9. Nicholson, S.E.; Some, B.; Kone, B. An analysis of recent rainfall conditions in west Africa, including the rainy seasons of the $1997 \mathrm{El}$ Niño and the 1998 La Niña years. J. Clim. 2000, 13, 2628-2640. [CrossRef]

10. Pinzon, J.E.; Tucker, C.J. A non-stationary 1981-2012 AVHRR NDVI3g time series. Remote Sens. 2014, 6, 6929-6960. [CrossRef]

11. Tucker, C.J.; Pinzon, J.E.; Brown, M.E.; Slayback, D.A.; Pak, E.W.; Mahoney, R.; Vermote, E.F.; El Saleous, N. An extended AVHRR 8-km NDVI dataset compatible with MODIS and SPOT vegetation NDVI data. Int. J. Remote Sens. 2005, 26, 4485-4498. [CrossRef] 
12. Anyamba, A.; Tucker, C.J. Analysis of Sahelian vegetation dynamics using NOAA-AVHRR NDVI data from 1981-2003. J. Arid Environ. 2005, 63, 596-614. [CrossRef]

13. Eklundh, L.; Olsson, L. Vegetation index trends for the African Sahel 1982-1999. Geophys. Res. Lett. 2003, 30, 1430-1433. [CrossRef]

14. Olsson, L.; Eklundh, L.; Ardo, J. A recent greening of the Sahel-trends, patterns and potential causes. J. Arid Environ. 2005, 63, 556-566. [CrossRef]

15. Piao, S.; Wang, X.; Park, T.; Chen, C.; Lian, X.; He, Y.; Bjerke, J.W.; Chen, A.; Ciais, P.; Tømmervik, H.; et al. Characteristics, drivers and feedbacks of global greening. Nat. Rev. Earth Environ. 2020, 1, 14-27. [CrossRef]

16. West, C.T.; Moody, A.J.; Nébié, E.K.; Sanon, O. Ground-truthing Sahelian greening: Ethnographic and spatial evidence from Burkina Faso. Hum. Ecol. 2017, 45, 89-101. [CrossRef] [PubMed]

17. Chen, C.; Park, T.; Wang, X.; Piao, S.; Xu, B.; Chaturvedi, R.K.; Fuchs, R.; Brovkin, V.; Ciais, P.; Fensholt, R.; et al. China and India lead in greening of the world through land-use management. Nat. Sustain. 2019, 2, 122-129. [CrossRef]

18. Zhu, Z.; Piao, S.; Myneni, R.B.; Huang, M.; Zeng, Z.; Canadell, J.G.; Ciais, P.; Sitch, S.; Friedlingstein, P.; Arneth, A.; et al. Greening of the Earth and its drivers. Nat. Clim. Chang. 2016, 6, 791-795. [CrossRef]

19. Georganos, S.; Abdi, A.M.; Tenenbaum, D.E.; Kalogirou, S. Examining the NDVI-rainfall relationship in the semi-arid Sahel using geographically weighted regression. J. Arid Environ. 2017, 146, 64-74. [CrossRef]

20. Herrmann, S.M.; Anyamba, A.; Tucker, C.J. Recent trends in vegetation dynamics in the African Sahel and their relationship to climate. Glob. Environ. Chang. 2005, 15, 394-404. [CrossRef]

21. Hickler, T.; Eklundh, L.; Seaquist, J.W.; Smith, B.; Ardö, J.; Olsson, L.; Sykes, M.T.; Sjöström, M. Precipitation controls Sahel greening trend. Geophys. Res. Lett. 2005, 32, L21415. [CrossRef]

22. Abdi, A.M.; Boke-Olén, N.; Tenenbaum, D.E.; Tagesson, T.; Cappelaere, B.; Ardö, J. Evaluating water controls on vegetation growth in the semi-arid Sahel using field and earth observation data. Remote Sens. 2017, 9, 294. [CrossRef]

23. Meroni, M.; Rembold, F.; Fasbender, D.; Vrieling, A. Evaluation of the standardized precipitation index as an early predictor of seasonal vegetation production anomalies in the Sahel. Remote Sens. Lett. 2017, 8, 301-310. [CrossRef]

24. Nemani, R.R.; Keeling, C.D.; Hashimoto, H.; Jolly, W.M.; Piper, S.C.; Tucker, C.J.; Myneni, R.B.; Running, S.W. Climate-driven increases in global terrestrial net primary production from 1982 to 1999. Science 2003, 300, 1560-1563. [CrossRef]

25. Charney, J.G. Dynamics of deserts and drought in the Sahel. Q. J. R. Meteorol. Soc. 1975, 101, $193-202$. [CrossRef]

26. Folland, C.K.; Palmer, T.N.; Parker, D.E. Sahel rainfall and worldwide sea temperatures, 1901-1985. Nature 1986, 320, 602. [CrossRef]

27. Giannini, A.; Saravanan, R.; Chang, P. Oceanic forcing of sahel rainfall on interannual to interdecadal time scales. Science 2003, 302, 1027-1030. [CrossRef] [PubMed]

28. Palmer, T.N. Influence of the Atlantic, Pacific and Indian Oceans on Sahel rainfall. Nature 1986, $322,251$. [CrossRef]

29. Lamb, P.J. Case Studies of tropical Atlantic surface circulation patterns during recent sub-saharan weather anomalies: 1967 and 1968. Mon. Weather Rev. 1978, 106, 482-491. [CrossRef]

30. Biasutti, M.; Held, I.M.; Sobel, A.H.; Giannini, A. SST forcings and Sahel rainfall variability in simulations of the twentieth and twenty-first centuries. J. Clim. 2008, 21, 3471-3486. [CrossRef]

31. Losada, T.; Rodriguez-Fonseca, B.; Mohino, E.; Bader, J.; Janicot, S.; Mechoso, C.R. Tropical SST and Sahel rainfall: A non-stationary relationship. Geophys. Res. Lett. 2012, 39, L12705. [CrossRef]

32. Pomposi, C.; Giannini, A.; Kushnir, Y.; Lee, D.E. Understanding Pacific Ocean influence on interannual precipitation variability in the Sahel. Geophys. Res. Lett. 2016, 43, 9234-9242. [CrossRef]

33. Dyer, E.L.E.; Jones, D.B.A.; Li, R.; Sawaoka, H.; Mudryk, L. Sahel precipitation and regional teleconnections with the Indian Ocean. J. Geophys. Res. Atmos. 2017, 122, 5654-5676. [CrossRef]

34. Park, J.Y.; Bader, J.; Matei, D. Anthropogenic Mediterranean warming essential driver for present and future Sahel rainfall. Nat. Clim. Chang. 2016, 6, 941-945. [CrossRef] 
35. Diatta, S.; Fink, A.H. Statistical relationship between remote climate indices and West African monsoon variability. Int. J. Climatol. 2014, 34, 3348-3367. [CrossRef]

36. Rodríguez-Fonseca, B.; Mohino, E.; Mechoso, C.R.; Caminade, C.; Biasutti, M.; Gaetani, M.; Garcia-Serrano, J.; Vizy, E.K.; Cook, K.; Xue, Y.; et al. Variability and predictability of West African droughts: A review on the role of sea surface temperature anomalies. J. Clim. 2015, 28, 4034-4060. [CrossRef]

37. Dong, B.; Sutton, R. Dominant role of greenhouse-gas forcing in the recovery of Sahel rainfall. Nat. Clim. Chang. 2015, 5, 757-760. [CrossRef]

38. Biasutti, M. Hydrology: What Brings Rain to the Sahel? Nat. Clim. Chang. 2016, 6, 897-898. [CrossRef]

39. Liang, X.S. Information flow and causality as rigorous notions ab initio. Phys. Rev. E 2016, $94,52201$. [CrossRef]

40. Hagan, D.F.T.; Wang, G.; Liang, X.S.; Dolman, H.A.J. A time-varying causality formalism based on the Liang-Kleeman information flow for analyzing directed interactions in nonstationary climate systems. J. Clim. 2019, 32, 7521-7537. [CrossRef]

41. Stips, A.; Macias, D.; Coughlan, C.; Garcia-Gorriz, E.; Liang, X.S. On the causal structure between $\mathrm{CO}_{2}$ and global temperature. Sci. Rep. 2016, 6, 21691. [CrossRef] [PubMed]

42. Zhu, Z.; Bi, J.; Pan, Y.; Ganguly, S.; Anav, A.; Xu, L.; Samanta, A.; Piao, S.; Nemani, R.; Myneni, R. Global data sets of vegetation leaf area index (LAI) $3 \mathrm{~g}$ and fraction of photosynthetically active radiation (FPAR) $3 \mathrm{~g}$ derived from Global Inventory Modeling and Mapping Studies (GIMMS) normalized difference vegetation index (NDVI3g) for the period 1981 to 2011. Remote Sens. 2013, 5, 927-948. [CrossRef]

43. Harris, I.; Jones, P.D.; Osborn, T.J.; Lister, D.H. Updated high-resolution grids of monthly climatic observations-The CRU TS3.10 Dataset. Int. J. Climatol. 2014, 34, 623-642. [CrossRef]

44. Huang, B.; Thorne, P.W.; Banzon, V.F.; Boyer, T.; Chepurin, G.; Lawrimore, J.H.; Menne, M.J.; Smith, T.M.; Vose, R.S.; Zhang, H.M. Extended reconstructed sea surface temperature, version 5 (ERSSTv5): Upgrades, validations, and intercomparisons. J. Clim. 2017, 30, 8179-8205. [CrossRef]

45. Biasutti, M. Forced Sahel rainfall trends in the CMIP5 archive. J. Geophys. Res. Atmos. 2013, 118, $1613-1623$. [CrossRef]

46. USGS 30 ARC-second Global Elevation Data, GTOPO30. 1997. Available online: https://www.usgs.gov/ centers/eros/science (accessed on 2 October 2018).

47. Kendall, M.G. Rank Correlation Methods; Charles Griffin: London, UK, 1975; p. 202.

48. Mann, H.B. Nonparametric tests against trend. Econometrica 1945, 13, 245-259. [CrossRef]

49. Sneyers, R. Sur L'analyse Statistique des Series D'observations; OMM: Geneve, Switzerland, 1975.

50. Zhang, Y.; Guan, D.; Jin, C.; Wang, A.; Wu, J.; Yuan, F. Analysis of impacts of climate variability and human activity on streamflow for a river basin in northeast China. J. Hydrol. 2011, 410, 239-247. [CrossRef]

51. Demaree, G.R.; Nicolis, C. Onset of Sahelian drought viewed as a fluctuation-induced transition. Q. J. R. Meteorol. Soc. 1990, 116, 221-238. [CrossRef]

52. Moraes, J.M.; Pellegrino, G.Q.; Ballester, M.V.; Martinelli, L.A.; Victoria, R.L.; Krusche, A.V. Trends in hydrological parameters of a southern Brazilian watershed and its relation to human induced changes. Water Resour. Manag. 1998, 12, 295-311. [CrossRef]

53. Toms, J.D.; Lesperance, M.L. Piecewise regression: A tool for identifying ecological thresholds. Ecology 2003, 84, 2034-2041. [CrossRef]

54. Wang, X.; Piao, S.; Ciais, P.; Li, J.; Friedlingstein, P.; Koven, C.; Chen, A. Spring temperature change and its implication in the change of vegetation growth in North America from 1982 to 2006. Proc. Natl. Acad. Sci. USA 2011, 108, 1240-1245. [CrossRef] [PubMed]

55. Myneni, R.; Knyazikhin, Y.; Park, T. MOD15A2H MODIS/Terra Leaf Area Index/FPAR 8-Day L4 Global $500 \mathrm{~m}$ SIN Grid V006; NASA EOSDIS Land Processes DAAC: Sioux Falls, SD, USA, 2015. [CrossRef]

56. Huffman, G.J.; Bolvin, D.T.; Nelkin, E.J.; Wolff, D.B.; Adler, R.F.; Gu, G.; Hong, Y.; Bowman, K.P.; Stocker, E.F. The TRMM Multisatellite Precipitation Analysis (TMPA): Quasi-Global, Multiyear, Combined-Sensor Precipitation Estimates at Fine Scales. J. Hydrometeorol. 2007, 8, 38-55. [CrossRef] 
57. Bernardino, P.N.; Keersmaecker, W.D.; Fensholt, R.; Verbesselt, J.; Somers, B.; Horion, S. Global-scale characterization of turning points in arid and semi-arid ecosystem functioning. Glob. Ecol. Biogeogr. 2020, 29, 1230-1245. [CrossRef]

58. Ackerley, D.; Booth, B.B.B.; Knight, S.H.E.; Highwood, E.J.; Frame, D.J.; Allen, M.R.; Rowell, D.P. Sensitivity of Twentieth-Century Sahel Rainfall to Sulfate Aerosol and $\mathrm{CO}_{2}$ Forcing. J. Clim. 2011, 24, 4999-5014. [CrossRef]

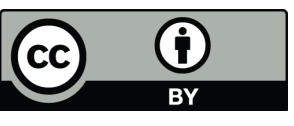

C 2020 by the authors. Licensee MDPI, Basel, Switzerland. This article is an open access article distributed under the terms and conditions of the Creative Commons Attribution (CC BY) license (http://creativecommons.org/licenses/by/4.0/). 